\title{
The Relationship Between Psychological Well-Being, Discipline and Online Gaming Addiction Among High School Students in Central Java
}

\author{
M. T. Afriwilda*, Mulawarman \\ Universitas Negeri Semarang \\ Semarang, Indonesia \\ *Mayang01@students.unnes.ac.id
}

\begin{abstract}
This study aimed to explore the relationship between online game addiction, psychological well-being and selfdiscipline. The research methodology is a quantitative approach with a correlational descriptive type. The samples used were 1046 high school students in Central Java. The Instruments used were the Psychological Well-Being Scale, Neo-PI Self-Discipline Scale, and Game Online Addiction Scale. Data were analysed using descriptive statistical techniques and multiple regression. The results showed psychological well-being and self-discipline simultaneously had a negative correlation with online game addiction. The analysis result also shows the percentage effect of psychological well-being and self-discipline on online game addiction. Then it is known psychological well-being has a negative effect on online game addiction. The same results were also shown for self-discipline variables which negatively affected online game addiction. An interesting profile has emerged from the results of this study, suggesting that certain psychological characteristics such as psychological well-being and selfdiscipline may predispose some individuals to become addicted to online games. This result will provide basic information that can contribute to developing a prevention program for students who are addicted to online games.
\end{abstract}

Keywords—psychologichal well-being, discipline, game online addiction

\section{INTRODUCTION}

Changes and updates in the field of technology are undeniable. The Industrial Revolution 4.0 is an era that combines automation technology with network technology, which brings many changes to the order of life $[1,2]$. The internet is one of the real proofs of technological developments. Internet can be used by anyone, anytime, anywhere. The progress of the internet is expected to have a positive impact on improving the quality of human life. The internet can be used for various purposes, such as browsing, chatting, watching videos on YouTube or playing online games [3].

If online games are used for entertainment activities it will have a positive impact, and all fatigue and stress can be reduced by playing games [4]. Shaffer, Squire, Halverson, and Gee show that online games have the ability to attract students, enabling them to easily collaborate with each other using language in easy-to-understand media [5]. However, if one plays these online games too often, it can lead to addiction. The term addiction was originally used only for alcohol and drugs. But now the term "addiction" can be used for other things, including playing online games [6]. Addiction is a condition in which individuals feel dependent on something they like due to lack of control over behaviour.

According to Young, if teenagers have been playing online games for 6 months since they first started playing online games, they will be addicted to online games [7]. Delfabbro and Griffiths stated that if teenagers spend 35 hours a week playing online games, they will become addicted, meaning they can spend up to 5 hours playing games in a day [8]. The American Psychological Association has confirmed that study jobs exceeding 5 hours a day require use of online games, social networks or the Internet, and continuous use is said to be addictive.

A person who is addicted to online games will usually experience symptoms such as salience (thinking of playing online games all day), tolerance (when playing online games increases, mood modification (feeling bad about not being able to play online games), relapse (tendency to play games). online again after not playing for a long time), withdrawal (playing online games to get away from the problem), conflict (fighting with other people due to excessive playing online games), and problems (ignoring other activities causing problems) The seven criteria for online game addiction This is a measure to determine whether an online game player has an addiction, if a player meets four of the seven criteria, it is an indication that the player is addicted to online games [7].

The impact of online game addiction includes five aspects, namely health, psychological, academic, social and financial [9]. In Indonesia, several studies have shown that online game addiction causes students to be unable to stop playing, fatigue, truancy, lack of social interaction, hallucinations, decreased academic achievement, rude and disrespectful speech and 
behaviour, to crimes such as stealing parents' money, and become undisciplined [10-12].

Discipline is important for students to improve their learning outcomes. Discipline is a form of self-control, forming a moral character, correcting it with sanctions, and a collection of several rules for regulating behaviour. Discipline is very important in teaching and learning activities in schools. This attitude can create a comfortable and conducive learning atmosphere for learning. Self-discipline, sacrifice, and effort are needed in order to fulfil the potential of individuals who focus on psychological well-being [13].

Meanwhile, according to Winther [14] states that the factor that affects low psychological well-being is excessive internet use. Meanwhile, Young stated that the internet feature that makes users addicted is online games. This means that the influence of the internet that causes users to experience addiction is internet access to online games. According to Aspinwall, psychological well-being describes how well psychologically functions and positively. Furthermore, according to Schultz [15] defines psychological wellbeing as a positive individual function, where the positive function of the individual is the direction or goal that a healthy individual strives to achieve.

The phenomenon that occurs in adolescents at this time seems unable to fulfil every dimension of psychological wellbeing, namely low self-acceptance, as shown in adolescents who feel dissatisfied with themselves because they are disappointed with what has happened in the past and because of past experiences. Then what is disappointing makes adolescents begin to experience barriers in personality qualities and feel different from what they are.

Likewise, Ryff [16] stated that psychological well-being does not only consist of positive effects, negative effects, and life satisfaction, but is best understood as a multidimensional construct consisting of life attitudes related to the dimensions of psychological well-being itself, namely being able to realize one's potential continuously, being able to form warm relationships with others, having independence from social pressures, as well as accepting oneself as it is, having meaning in life, and being able to control the external environment. Based on the things that have been disclosed, this study aims to determine the relationship between discipline, psychological well-being and online game addiction in students.

\section{METHODS}

This study uses a correlational research design with a survey method. The number of respondents in this study amounted to 1046 high school students in Semarang City who were randomly selected (random-assignment). This study uses three scales, namely, the Psychological Well-being scale made by Carol D Ryff. This scale consists of six mutually correlated elements, namely autonomy, environmental mastery, personal growth, positive relations with others, purpose in life, and selfacceptance. The psychological well-being scale used in this study is a medium form of 42 items with 3 items per aspect
[17]. This instrument has a Cronbach Alpha score of 0.908 . Second, the NEO-PI the International Personality Item Pool self-discipline scale created by Blach, Aluja, Gallart, Dolcet [18]. This scale consists of 10 items with a Cronbach Alpha 0.850. Third, the psychology scale of online game addiction made by Lemmens et al [7]. This scale consists of 21 items with 3 items per aspect related to the seven criteria for addiction to online games according to Lemmens, Valkenburg and Peter namely silence, tolerance, mood modification, relapse, withdrawal, conflict and problems. This instrument has a Cronbach Alpha score of 0.860 . The assessment of the instrument is in the form of a Likert scale, where there are favourable statements and some are unfavourable with six answer choices ranging from strongly agree to strongly disagree. Data analysis using correlation analysis and multiple linear regression. Researchers used the application of Statistical Product and Service Solution (SPSS) version 21

\section{RESULTS AND DISCUSSION}

\section{A. Hypothesis Test Results}

TABLE I. DESCRIPTIVE DATA

\begin{tabular}{|l|l|l|l|l|l|}
\hline \multirow{2}{*}{ Variable } & \multirow{2}{*}{$\mathbf{M}$} & \multirow{2}{*}{ SD } & \multicolumn{3}{|c|}{ Range } \\
\cline { 4 - 6 } & & & Low & Middle & High \\
\hline PWB & 168.67 & 168.67 & 292 & 411 & 343 \\
\hline Discipline & 32.99 & 32.99 & 249 & 233 & 564 \\
\hline GOD & 44.85 & 14.05 & 517 & 355 & 174 \\
\hline Total & \multicolumn{5}{|l}{1046} \\
\hline
\end{tabular}

Based on the demographic data described in table 1, it can be seen that the total respondents in this study were 1046 students. Based on, descriptive analysis on each variable can be seen in table 1. It is known that the psychological well-being variable obtained a value $(M=168.67 ; S D=2.57)$. Then the self-discipline variable is known to be the value $(\mathrm{M}=32.99$; $\mathrm{SD}=4.59$ ). Meanwhile, the online game addiction variable obtained the value $(\mathrm{M}=44.85 ; \mathrm{SD}=14.05)$. For the low category psychological wellbeing variable amounted to 292 (27.9\%), medium 411 (39.2\%), high 343 (32.9\%), meanwhile for the low category discipline variable amounted to 249 $(23.9 \%)$, medium $233(22.2 \%)$, and $621(53.9 \%)$ high and the last for the online game addiction variable, the low category amounted to 517 (49.4\%), medium 355 (33.9\%), high 174 $(16.7 \%)$.

\section{B. Multicollinearity Test Results}

TABLE II. Multiple REgRESSION ANALYSIS RESUlts

\begin{tabular}{|l|c|c|c|c|c|c|c|}
\hline \multicolumn{1}{|c|}{ Predictor } & $\boldsymbol{\beta}$ & $\mathbf{t}$ & $\mathbf{p}$ & $\mathbf{R}$ & $\boldsymbol{R}^{2}$ & $\mathbf{F}$ & $\mathbf{P}$ \\
\cline { 1 - 1 } $\begin{array}{l}\text { Psychological } \\
\text { Well-being }\end{array}$ & -0.169 & -5.32 & 0.00 & 0.339 & 0.113 & 67.58 & 0.00 \\
\hline Discipline & -0.531 & -4.609 & 0.00 & & & & \\
\hline
\end{tabular}


In table 2, it can be seen that the results of the multiple regression analysis show that psychological well-being and self-discipline simultaneously affect online game addiction $(\mathrm{F}$ _ $((2.1043))=67.58, \mathrm{p}<0.05)$. The analysis result also shows the percentage effect of psychological well-being and selfdiscipline of $11.3 \%$ on online game addiction $\left(\mathrm{R}^{\wedge} 2=0.113\right)$. Then it is known psychological well-being has a negative effect on online game addiction $(\beta=-0.169, p<0.05)$. The same results were also shown in the self-discipline variable which negatively affected online game addiction $(\beta=-0.531, p$ $<0.05)$.

Then, based on the results of the correlation analysis without controlling for the discipline variable, the correlation coefficient score was -0.169 with a significance value of $p=$ 0.00 ( $p<0.01)$. This shows that there is a very significant negative relationship between psychological well-being and the tendency to addiction to online games. The results of further correlation analysis between the discipline variable and not controlling for the psychological well-being variable, obtained a correlation coefficient score of -0.531 with a significance of $p$ $=0.000(\mathrm{p}<0.01)$. This shows that there is a very significant negative relationship between discipline and the tendency to addiction to online games.

The results of the analysis show that there is a significant negative relationship between discipline and psychological well-being with the tendency of online game addiction in students. This means that the higher the level of psychological well-being and discipline, the lower the tendency for online game addiction to be. Likewise, the current literature highlights the difference between 'involved use' and 'problematic use' of gaming (with problematic use often called 'game addiction', where game play impacts real-life functions; while involved use involves a number of big time invested without neglecting real life responsibilities). Literature suggests that problematic play leads to negative outcomes, while the play involved does not. The results of this study are in line with research conducted by Goh, Jones and Acapello which shows that online games tend to emphasize their negative impact on psychological well-being, with research showing that online game players are more vulnerable to negative psychological and physical impacts [19]. In addition, research on forms of Internet excessive use including online gaming shows that uncontrolled or compulsive use has been known to have negative effects on psychological well-being, such as depression and loneliness [20].

The results of this study also in line with previous research conducted by Cardak [21], which states that online game addiction is part of internet addiction affecting psychological well-being, students who have high internet addiction will lower their psychological well-being. Other studies have also revealed that addicted internet users have lower well-being than non-addicted users. In line with Wang's previous research, revealed that online game users who experience addiction are associated with decreased well-being, including low selfesteem, low life satisfaction and increased depression. In line with the description above, it can be seen that online game addiction is something that needs attention because it has a negative impact that affects psychological well-being [22].

For adolescents who are of school age, playing too much online games can have a bad impact, this statement is supported by the results of research showing that people who are addicted to online games have poor discipline and have a big impact on themselves [23]. Self-discipline, sacrifice, and effort are needed in order to fulfil the potential of individuals who focus on psychological well-being. Having good psychological well-being and discipline can reduce the negative impact of internet use, especially online gaming addiction. Because psychological well-being is needed by teenagers in their development process.

\section{CONCLUSION}

Based on the results of the study, it can be concluded that there is a negative relationship between self-control and selfesteem with the tendency to addiction to online games in students. The higher the discipline and psychological wellbeing in students, the lower the tendency for online game addiction to be, conversely, the lower the discipline and psychological well-being in students, the higher the tendency for online game addiction.

For further researchers, they should be able to conduct research with other factors that influence the tendency for online game addiction. In addition, further researchers are expected to be able to do different categories of subjects other than high school students. Further researchers can develop research measurement tools, to obtain higher reliability and validity of measuring instruments used in this study. The method used needs to be expanded by using other methods such as using the interview method to subjects who have a tendency to be addicted to online games and the experimental method.

\section{REFERENCES}

[1] V. Puncreobutr, "Education 4.0: New Challenge of Learning," St Theresa Journal of Humanities and Social Sciences, vol. 2, no. 2, 2016.

[2] A. Rojko, "Industry 4.0 Concept: Background and Overview," International Journal of Interactive Mobile Technologies (iJIM), vol. 11, no. 5, pp. 77-90, 2017.

[3] C.T.Y. Yeung and R.C.F. Chui, "A Study on the Impact of Involvement in Violent Online Game and Self-Control on Hong Kong Young Adults' Psychological Well-Being," In New Media for Educational Change, pp. 165-174, 2018.

[4] C.V. Russoniello, K. O'Brien and J.M. Parks, "The effectiveness of casual video games in improving mood and decreasing stress," Journal of CyberTherapy \& Rehabilitation, vol. 2, no. 1, pp. 53-66, 2009.

[5] D.W. Shaffer, K.R. Squire, R. Halverson and J.P. Gee, "Video game and the future of learning," Phi delta kappan, vol. 87, no. 2, pp. 105-111, 2005 .

[6] P.O. Fanny and O. Usman, "Influence of Behavior, Time Management, Motivation, and Self-Control on Addiction to Playing Online Games," Time Management, Motivation, and Self-Control on Addiction to Playing Online Games, 2020. 
[7] J.S. Lemmens, P.M. Valkenburg and J. Peter, "Development and validation of a game addiction scale for adolescents," Media psychology, vol. 12, no. 1, pp. 77-95, 2009.

[8] D.L. King and P.H. Delfabbro, "Video game monetization (eg, 'loot boxes'): a blueprint for practical social responsibility measures," International Journal of Mental Health and Addiction, vol. 17, no. 1, pp. 166-179, 2019.

[9] T.A. Sandy and W.N. Hidayat, Game mobile learning. Ahlimedia Book, 2019.

[10] N.A. Efendi, Faktor Penyebab Bermain Game Online Dan Dampak Negatifnya Bagi Pelajar (Studi Kasus pada Warung Internet di Dusun Mendungan Desa Pabelan Kecamatan Kartasura Kabupaten Sukoharjo). (Doctoral dissertation, Universitas Muhammadiyah Surakarta), 2014.

[11] D.E. Kurniawan, "Pengaruh Intensitas Bermain Game Online Terhadap Perilaku Prokrastinasi Akademik Pada Mahasiswa Bimbingan dan Konseling Universitas PGRI Yogyakarta," Jurnal Konseling GUSJIGANG, vol. 3, no. 1, 2017.

[12] I.D.P. Eskasasnanda, "Causes and Effects of Online Video Game Playing among Junior-Senior High School Students in Malang East Java," Komunitas: International Journal of Indonesian Society and Culture, vol. 9, no. 2, 2017.

[13] M.F. Grossbaum and G.W. Bates, "Correlates of psychological wellbeing at midlife: The role of generativity, agency and communion, and narrative themes," International Journal of Behavioral Development, vol. 26, no. 2, pp. 120-127, 2002.

[14] Al-Jawharah, "Relationship of Internet Use and Psychological WellBeing Among Students in Princess Nourah University," Indian Journal of fundamental, vol. 6, no. 3, pp. 58-68, 2016.
[15] D.P. Schultz, A History Modern of Psychology. Canada: Wardsworth. Cencage Learning, 2011.

[16] C.D. Ryff, "Psychological well-being in adult life," Current directions in psychological science, vol. 4, no. 4, pp. 99-104, 1995.

[17] C.D. Ryff, "Psychological well-being revisited: Advances in the science and practice of eudaimonia," Psychotherapy and psychosomatics, vol. 83, no. 1, pp. 10-28, 2014.

[18] A. Aluja, A. Blanch, D. Sole, J.M. Dolcet and S. Gallart, "Shortened versions of the NEO-PI-R: the NEO-FFI versus the NEO-FFIR,"Behavioral and Psychology-Psicologia Conductual, vol. 17, no. 2, pp. 335-350, 2009.

[19] C. Goh, C. Jones and A. Copello, "A further test of the impact of online gaming on psychological wellbeing and the role of play motivations and problematic use," Psychiatric Quarterly, vol. 90, no. 4, pp. 747-760, 2019.

[20] C. Morgan and S.R. Cotten, "The relationship between Internet activities and depressive symptoms in a sample of college freshmen," CyberPsychology \& Behavior, vol. 6, no. 2, pp. 133-142, 2003.

[21] C. Cardak, "Psychological well-being and internet addiction Among University Student," The Turkish Online Journal of Educational Technology, vol. 12, no. 3, 2013.

[22] L. Wang, J. Luo, Y. Bai, J. Kong, J. Luo, W. Gao and X. Sun, "Internet addiction of adolescents in china: prevalence prediktors, and association with well- being," Addiction Research \& Theory, vol. 21, no. 1, pp. 62 69, 2013.

[23] R.B. Liminanto, "Pengaruh Bermain Game online terhadap Disiplin Belajar Siswa," KONSELING: Jurnal Ilmiah Penelitian dan Penerapannya, vol. 1, no. 2, pp. 49-54, 2020. 